田園地河川における水稲移植後の農葙流出量の評価

\author{
沼辺明愽* 茾上隆信** 海老瀬潜 一**
}

\title{
Estimation on the Runoff Amounts of Pesticides Applied after Transplanting of Rice Plant by Drainage River
}

\author{
Akihiro NUMABE*, Takanobu INOUE** and Senichi $\mathbb{E B I S E}^{* *}$ \\ * Hokkaido Institute of Environmental Sciences, kita-19 Nishi-12, Kita-ku, Sapporo 060 Japan \\ * National Institute for Environmental Studies, 16-2 Onogawa, Tsukuba, Ibaraki 305 Japan
}

\begin{abstract}
The runoff loadings and characteristics of pesticides applied to paddy fields after transplanting of rice plant were estimated by means of analysis of pesticides in drainage river water in weekly and at the rainfall events.

The largest loadings of herbicides were found between one and two weeks after transplanting of rice plant. On the other hand, the largest loadings of insecticides were found at about ten days later than that of herbicides.

The runoff loadings of herbicides during one rainfall event ranged 20 to $25 \%$ of total runoff amounts. Therefore, the runoff investigation of pesticides in river water at and after the rainfall are very important for estimation of pesticides runoff from agricultural fields to drainage river.

The runoff characteristics of insecticides and herbicides were differed, and it was recognized that the runoff loadings of insecticides were decreased more rapidly than herbicides at the rainfall event.

The runoff rates of pesticides were ranged from $25 \%$ for fenobucarb to $0.02 \%$ for fenitrothion.

From this results concerned in rainfall event, the runoff rates of pesticides from agricultural fields to river were more higher than that of the previous literature.
\end{abstract}

Key words : pesticides, paddy field, rainfall, runoff characteristics, runoff rates

\section{1. 緒言}

近年, ゴルフ場で施用される農薬による環境污染が 大きな社会問題として取り上げられている。しかし， ゴルフ場で施用される嶩萗は全施用量の $1 \%$ 程度で, 98\%以上は農林業用に用いられ，さらに，穴の約半量 が水田で施用されている1”。水田は河川等の水系と密 接につながっており，㠔薬による環境污染を引き起こ す危険性が高く，1970年代までは農薬の流出による魚
介類のへい死が数多く報告された22。その後, 毒性や残 留性の高い農薬の施用は規制され，被害の発生もあま り聞かれなくなったが，低濃度長期暴露や複合作用に よる水生生物等の自然生態系への影響についても関心 がもたれている31,4)。

農薬による微量污染を抑えるための最も有効な手段 は流出をいかに制御するかである。このためには，数 多く施用されている農薬の流出特性を知ることが前提 となる。農薬の環境への流出に関する報告は数多く見

* 北游道㻴境科学研究センター T060 札缶市北区北19条西12丁目

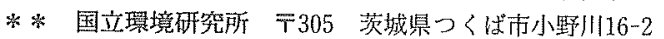




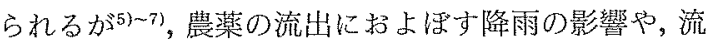
量観測と農薬施用量調㚗に基づいて流出負荷量と流出 率を詳細に検討した報告はあまりみられない。

本報告では，1991年 5，6月の 2 力月間に，每週 1 回定時の定期調查と降雨後の追加調查に加元，降雨時 流出調㚗を行い，水稲移植期に施用される農薬の流出 特性を明らかにし，総流出負荷量と調査頻度の関係に ついて考察した。さらに，調査流域への農薬の出荷量 調查を行い，各農薬の流出率について検討した。

\section{2, 調 笪概要}

\section{1 調查地域の概要}

調查地点は，霞っ浦高浜入に流入する恋瀬川の支流 小桜川を中心に Fig.1に示す 6 地点で，全流域面積は $127.5 \mathrm{~km}^{2}$ ，調査区間の流路延長は約 $6.6 \mathrm{~km}$ である。

小桜川の St. 1，3，4には流路内に取水堰が設けら れ，周辺の水田にポンプで灌湼用水を供給している。 小桜川には，ほかにも St. 1 と St. 2 の間に 2 力所, St. 3 と St. 4 の間に 1 力所のポンプ場がある。さらに,川

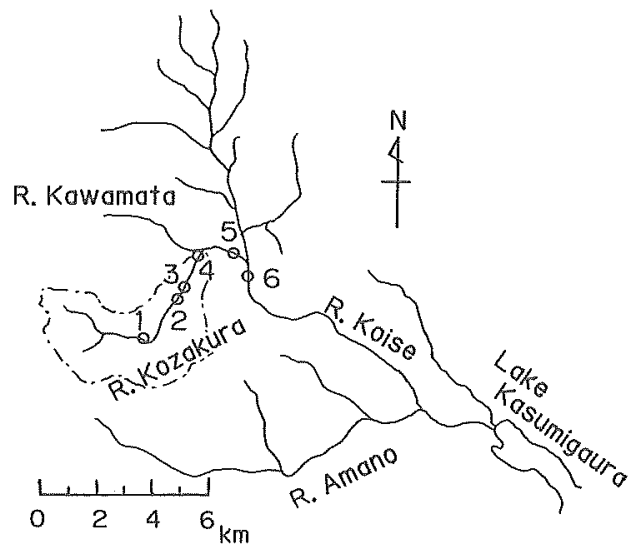

Fig. 1 Location of observation points
又川，恋瀬川にも多くのポンプ場があり，河川水は灌 溉用水として繰り返し使用されている。取水堰は St. 1 にみられる簡単な羽目板式のものと，St. $3 ， 4$ などに 設置されているラバーダム方式のものがある。後者は ゴム製の垵を空気で膨らませ止水するもので，增水時 には自動的に堰の空気が抜けて開放されるようになっ ている。

各調査地点每の流域面積，利用形態別農耕地面積を Table 1 に示卞。各調查地点每の流域面積に占める農 耕地面積の比率は，小桜川の上流 (St. 1) $5.5 \%$ ，小桜 川 (St. 4) 16\%，川又川 (St. 5 ) 21\%, 恋瀨川 (St. 6) $25 \%$ である。農耕地の利用形態としては水田が最も多 く54〜 64\%を占め，次いで，小桜川と川又川の流域で は畑地と樹園地がほほ同面積(14 20\%)，恚瀬川流域 では烟地 (27.5\%)，樹園地（13.5\%）の順である。ま た，下流医ど水田面積の割合が減少し，そ机にともな い畑地の比率が堌加する。な沾，水田の約 1 割は休耕 田であった。

\section{2 調㚗方法}

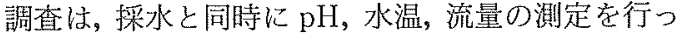
た。試料は，農薬分析用には $500 \mathrm{ml}$ の褐色ガラス瓶， SS 等の分析用には $1 l$ のポり唒を用い, 流路のほほ 央約 $10 \mathrm{~cm}$ の深さから直接採取した。試料は水冷して 実験室に持ち㷌り，直ちに分析を行った。流量は既報8 と同様, 流水断面積の計測とプロペラ型流速計による 流速測定から求めた。ポンプ場のあるSt. 1 と St. 4 は 灌激用水の取水直後, St. 3 は直前を調查地点とした。 降水量江調查地域に最も近い水戸地方気象台柿岡気象 観測所のデータを用いた。

この地域の水稲移植は，おもに 4 月 27 日から 5 月 6 日のゴールデンウィーク期間中に行われ，特に，連休 後半（5月 3 日〜 6 日）に集中した。調查期間は移植 が本格化する前の 5 月 1 日から 6 月26日までの57日間 とし，每週水曜日に 9 回の定期調査， $10 \mathrm{~mm}$ 前後の降 雨後に 8 回の追加調查を行った。調查は，同時刻とな

Table 1 Classified area by land use types in observation basin

\begin{tabular}{|c|c|c|c|c|c|c|}
\hline & Distance & $\begin{array}{c}\text { Uatershed } \\
\text { area } \\
\left(\mathrm{kg}^{2}\right)\end{array}$ & $\begin{array}{c}\text { Agricultural } \\
\text { land } \\
\left(\mathrm{km}^{2}\right)\end{array}$ & $\begin{array}{c}\text { Paddy* } \\
\text { field } \\
\left(\mathrm{km}^{2}\right)\end{array}$ & $\begin{array}{l}\text { Ploned } \\
\text { field } \\
\left(\mathrm{km}^{2}\right)\end{array}$ & orchard \\
\hline St.1 & 0 & 9.4 & 0.521 & 0.29 & 0.074 & 0.052 \\
St.2 & 2.475 & 16.2 & 1.84 & 1.05 & 0.262 & 0.255 \\
St.3 & 2.725 & 16.5 & 2.02 & 1.16 & 0.279 & 0.291 \\
St.4 & 4.425 & 18.2 & 2.93 & 1.66 & 0.460 & 0.456 \\
St.5 & 5.575 & 39.8 & 8.23 & 4.19 & 1.61 & 1.63 \\
St.6 & 6.575 & 127.5 & 31.8 & 15.6 & 8.75 & 4.28 \\
\hline
\end{tabular}

; Cultivated paddy field 
るように 9 時半前後に上流の小桜川St. 1 より開始し, 涊瀬川のSt. 6 まで約 3 時間を要した。

降雨時流出調査は，小桜川末流地点 (St. 4) 飞おい て，5月15日から16日の降雨について行った。採水は 16日3 時20分から15時悉でに，河川の流量変化に応じ て30分から90分の間隔で 9 回行った。

農䕓の流出率は，農協における出荷量より算出した。 1991年 2 月から 6 月の 5 力月間以農拹から調查流域に 販売された全農薬量を地域別に調べ，農菜製郕每の有

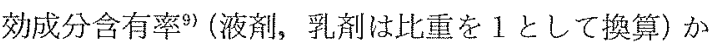
ら各成分の出荷量索調査地点流域每に算出した。

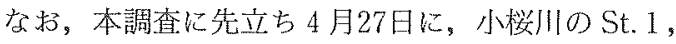
$3 ， 4$ において農嵲分析用のための採水を行っている。

\section{3 分析方法}

調查対象農薬は施用量の多い成分の中から標準品が 入手でき，同一操作で分析可能な除草殽 5 種；Mefenacet (MFN), Pyrazoxyfen (PYR), Butachlor (BUT), Pretilachlor (PRE), Esprocarb (ESP), 殺 虫剤 3 種：Fenobucarb (BPMC), Fenthion (MPP), Fenitrothion (MEP) である。

分析試料の調製は，試水 $400 \mathrm{~m} l$ をアセトンで洗浄し たガラス繊維沪紙 (Whatman GF/C) を用いて吸引沪 過し，沪液は溶存熊，沪紙は懸濁態の分析試料とした。 溶存態の分析は, 汇液を ODS ラム (Bond Elute C18）に約 $10 \mathrm{~m} l \cdot \mathrm{min}^{-1}$ の流速で吸引しながら，農薬を カラムに吸着させた。カラムを遠沈管に入れ， $3,000 \sim 4,000 \mathrm{rpm}$ で20分間遠心脱水後，アセトン 6 $\mathrm{m} l$ で農薬を溶出させた。アセトン溶液は遠心濃縮機 で約 $1 \mathrm{~m} l$ まで濃縮し，さらに純窒素がスを吹き付け てアセトンを揮散させた後, へキサン $1 \mathrm{~m} l$ に転溶し た。これを冷凍庫に入れて残留した水分を凍結分離後, ガスクロマトグラフ $(\mathrm{GC})$ で定量した。㩓濁態は，沪 紙を $100 \mathrm{~m} l$ の三角フラスコに入れ，アセトン $10 \mathrm{~m} l$ を 加党超音波に上る抽出を 3 回繰り返した。抽出液は遠 心濃縮機で約 $1 \mathrm{~m} l$ まで濃縮し, 蒸留水で約 $300 \mathrm{~m} l$ に 希釈後，溶存態と同椂の方法で分析した。へキサン溶 液は GCで定量するまで统冷谏庫内に保存した。

蒸留水 $400 \mathrm{~m} l に \mathrm{MEP}, \mathrm{MPP} を 0.1 \mu \mathrm{g}$ ，その他の蜄 薬を2 $\mu \mathrm{g}$ 添加して得られた回収率，および定量下限 値を Table 2 に示す。本報告ではこれらの回収率によ る禣正は行っていない。
GCの分析条件は下記のとおりである。

$\mathrm{GC}$ : 島津 GC-14A (FTD 検出器)

カラム : DB-1, 0.53mm i.d., $30 \mathrm{~m}$ Length

$1.5 \mu \mathrm{m}$ Film Thickness

カラム温度 $: 100^{\circ} \mathrm{C}(1 \mathrm{~min}) \rightarrow 8^{\circ} \mathrm{C} \cdot \mathrm{min}^{-1} \rightarrow 260^{\circ} \mathrm{C}$ ( $3 \mathrm{~min}$ )

注入口温度 : $250^{\circ} \mathrm{C}$

キャリアーガス: He $50 \mathrm{ml} \cdot \mathrm{min}^{-1}$

\section{3，結果と考察}

\section{1 農菜の流出特性}

St. 4 杇よびSt. 6 の河川流量の变化を降水量と共に Fig. 2 に示す。月間降水量は 4 月 $98 \mathrm{~mm}, 5$ 月 $112 \mathrm{~mm}$, 6 月 $139 \mathrm{~mm}$ であった。調查期間中の一降雨における最 大降水量は 6 月22 24日の $49 \mathrm{~mm}$ であるが， 3 日間に わたる降雨のため平均降雨強度は小さい。次いで， 6 月13〜14日の32mm，5月15〜16日の29mm と, 例年に 此べ降水量は少なかった。降雨後に河川流量は增加す るが減衰も速く，降雨の影響が䫒著にみられたのは， 降雨後十数時間程度であった。St. 4 の最大流量は, 降 雨時流出調查の5月16日に見られた。他の地点では， 5 月16日の調查を行っていないため，この降雨時調疽 のデータを除いて比較すると, St. 4 と St. 6 は同様の 流出パターンを示した。他の調查地点に関してもSt. 6 と同樣であった。

Fig. 3〜5に, St. 1，4，6における除草剂(BUT, MFN，PRE) の濃度と流出負荷量おるび殺虫剂 (MEP，MPP) の流出負荷量の経日変化を溶存態につ いて図示した。St.4については 5 月16日のデータを含 めて示した。Table 3 には各調查地点に抢ける農薂の 最高灙度と最大負荷量示した。

㲘濁態は MFN, MPP, MEP が降雨後の堌水時に検 出された。MEP は懸濁態の流出割合が10〜 $40 \%$ と大 きいが, MFN と MPP は $1 \%$ 以下で大半が溶存態と して流出していることが明らかとなった。

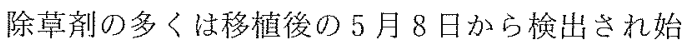
め，5月20日過ぎまで高い濃度で推移している。最高 濃度は 5 月13 15日に多く観測された。流出真荷量も 5 月10〜23日に多く, 最大負荷量は5月13日に出現し たものが多かった。St. 4 では 5 月16日の降雨時調査で 最大負荷量が見られ，施用最盛期の降雨により除草剂

Table 2 Detection limits and recovery of pesticides spiked into distilled water

\begin{tabular}{|c|c|c|c|c|c|c|c|c|}
\hline & MFN & PYR & BUT & PRE & ESP & BPMC & MPP & HEP \\
\hline Recovery ratio $(\%)$ & 92.4 & 85.0 & 86.1 & 91.0 & 74.9 & 85.9 & 70.5 & 90.9 \\
\hline Detection linit $\left(\mu \mathrm{g}, \mathrm{l}^{-1}\right)$ & 0.1 & 0.25 & 0.2 & 0.1 & 0.1 & 0.1 & 0.005 & 0.006 \\
\hline
\end{tabular}




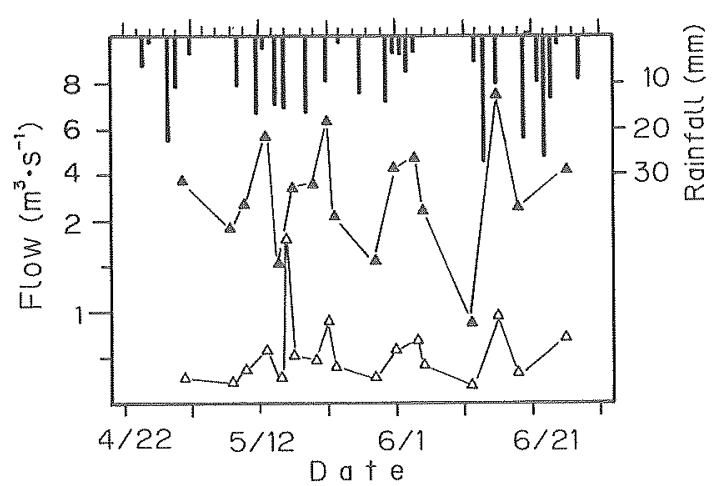

Fig. 2 Changes of flow rate at St. 4 and St. 6 $\triangle$ :St. 4 St. 6

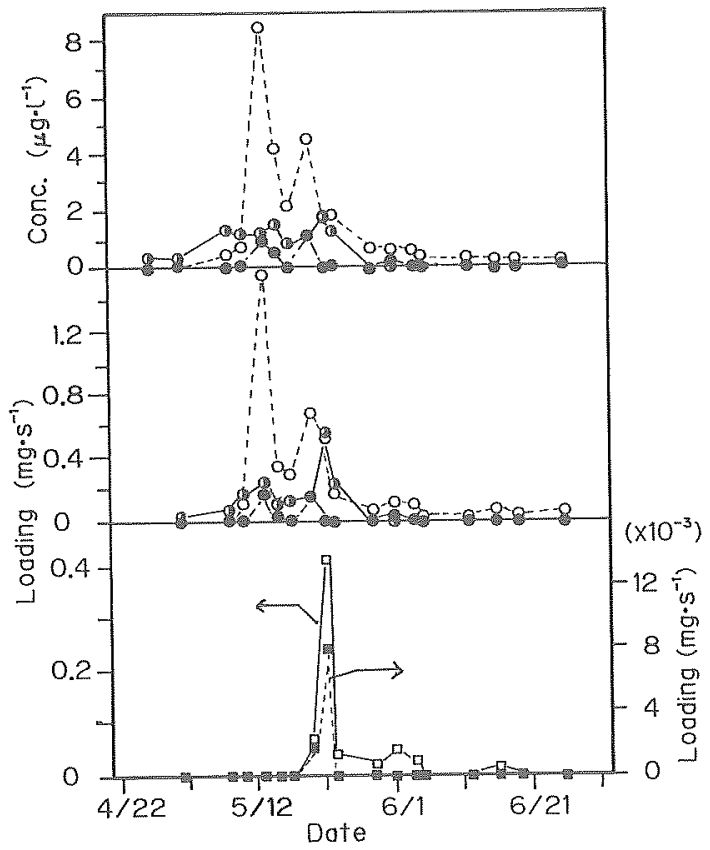

Fig. 3 Changes in concentration and loading of dissolved pesticides at St. 1

$$
\begin{aligned}
& \text { O:MFN ; :BUT; : PRE: } \\
& \square: \text { MPP ; }: \text { MEP }
\end{aligned}
$$

が多量に流出することが明らかとなった。小桜川での 除草剂は濃度の高い時期に下流ほど溲度が高くなる傾 向が見られた。飯塚 ${ }^{10)}$ 灌筑用水の反復利用により下 流部で除草威の婊茛か高くなることを報告している。

殺出剂のBPMCと MPP は同樣の流出パターンを 示し，除草用と同样5月8日頃加ら检出されるが。小 桜川では濃度，負荷量とも除草刘上り1週間から10日 ほど選れて 5 月20日頃にピークが見られた。川又川，

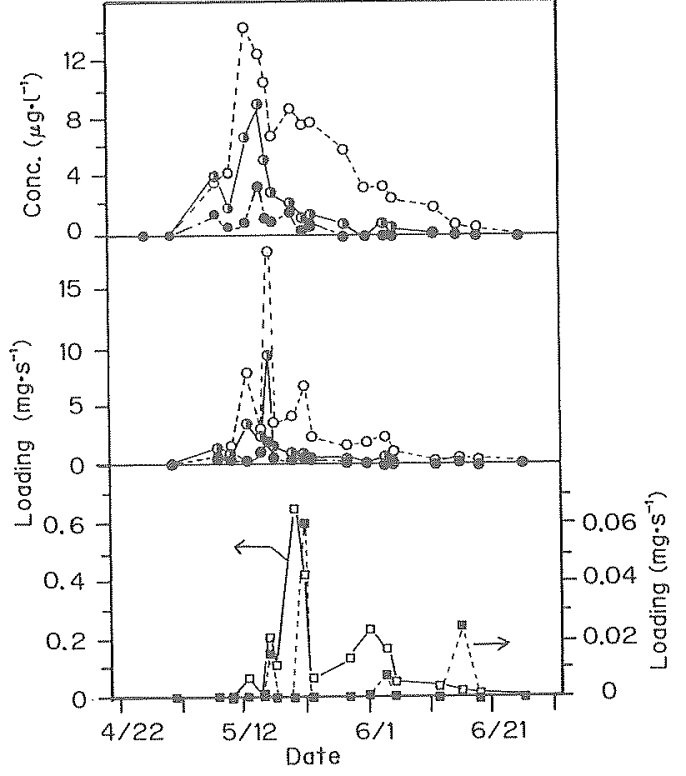

Fig. 4 Changes in concentration and loading of dissolved pesticides at St. 4

$0:$ MFN ; : BUT ; : PRE ;

$\square:$ MPP ; $:$ MEP

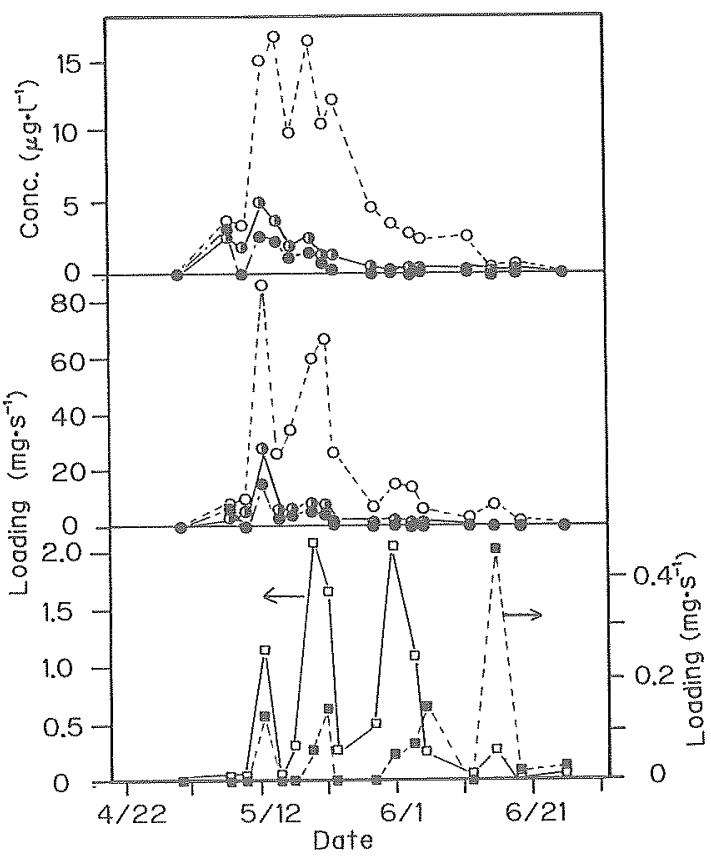

Fig. 5 Changes in concentration and loading of dissolved pesticides at St. 6

O MFN : : BUT : : PRE ;

口 : MPP ; : MEP 
Table 3 Maximum concentrations and loadings of pesticides at sampling sites

\begin{tabular}{|c|c|c|c|c|c|c|c|c|c|c|c|c|c|c|c|c|c|}
\hline \multirow{2}{*}{ St. 1} & \multirow{3}{*}{$\begin{array}{l}\text { Conc } \\
\text { Load }\end{array}$} & \multicolumn{2}{|c|}{ BU' } & \multicolumn{2}{|c|}{ PRE } & \multicolumn{2}{|c|}{ PYR } & \multicolumn{2}{|c|}{$M F N$} & \multicolumn{2}{|c|}{ ESP } & \multicolumn{2}{|c|}{ BPMC } & \multicolumn{2}{|c|}{ MPP } & \multicolumn{2}{|c|}{$M E P$} \\
\hline & & $5 / 22$ & 5.36 & $5 / 20$ & 0.92 & & 0 & $5 / 13$ & 8.36 & $5 / 13$ & 5.36 & $5 / 22$ & 12.4 & $5 / 22$ & 1.31 & $5 / 22$ & 0.025 \\
\hline \multirow{3}{*}{ St. 2} & & $5 / 22$ & 0.56 & $5 / 13$ & 0.16 & & 0 & $5 / 13$ & 1.52 & $5 / 13$ & 0.98 & $5 / 22$ & 3.95 & $5 / 22$ & 0.42 & $5 / 22$ & 0.008 \\
\hline & Cone & $5 / 15$ & 5.50 & $5 / 15$ & 1.72 & $5 / 20$ & 0.43 & $5 / 13$ & 6.04 & $5 / 15$ & 4.75 & $5 / 20$ & 14.2 & $5 / 20$ & 2.34 & $5 / 22$ & 0.072 \\
\hline & Load & $5 / 13$ & 2.49 & $5 / 20$ & 0.72 & $5 / 20$ & 0.22 & $5 / 13$ & 4.03 & $5 / 13$ & 2.17 & $5 / 22$ & 7.20 & $5 / 20$ & 1.17 & $5 / 22$ & 0.052 \\
\hline \multirow[t]{2}{*}{ St. 3} & Conc & $5 / 13$ & 5.08 & $5 / 20$ & 1.65 & $5 / 20$ & 0.38 & $5 / 13$ & 7.86 & $5 / 13$ & 4.33 & $5 / 20$ & 14.8 & $5 / 20$ & 2.34 & $5 / 22$ & 0.056 \\
\hline & Load & $5 / 13$ & 2.87 & $5 / 20$ & 0.87 & $5 / 20$ & 0.20 & $5 / 13$ & 4.43 & $5 / 13$ & 2.44 & $5 / 20$ & 7.78 & $5 / 20$ & 1.23 & $5 / 22$ & 0.042 \\
\hline \multirow[t]{2}{*}{ St. 4} & Conc & $5 / 15$ & 9.02 & $5 / 15$ & 3.36 & $5 / 15$ & 0.58 & $5 / 13$ & 14.6 & $5 / 15$ & 6.03 & $5 / 20$ & 10.1 & $5 / 20$ & 1.45 & $5 / 22$ & 0.069 \\
\hline & Load & $5 / 16$ & 9.12 & $5 / 16$ & 1.88 & $5 / 16$ & 0.48 & $5 / 16$ & 18.4 & $5 / 16$ & 8.33 & $5 / 22$ & 6.65 & $5 / 20$ & 0.65 & $5 / 22$ & 0.060 \\
\hline \multirow[t]{2}{*}{ St. 5} & Conc & $5 / 15$ & 5.63 & $5 / 8$ & 3.63 & $5 / 15$ & 0.67 & $5 / 13$ & 16.5 & $5 / 15$ & 3.22 & $5 / 20$ & 7.55 & $6 / 1$ & 1.06 & $6 / 5$ & 0.144 \\
\hline & Load & $5 / 13$ & 8.87 & $5 / 8$ & 2.53 & $5 / 13$ & 0.84 & $5 / 13$ & 28.9 & $5 / 13$ & 5.13 & $5 / 20$ & 7.70 & $6 / 1$ & 1.36 & $6 / 16$ & 0.297 \\
\hline \multirow[t]{2}{*}{ St. 6} & Conc & $5 / 13$ & 5.02 & $5 / 8$ & 2.98 & $5 / 15$ & 0.67 & $5 / 15$ & 16.9 & $5 / 13$ & 3.91 & $5 / 20$ & 6.13 & $5 / 20$ & 0.60 & $6 / 5$ & 0.064 \\
\hline & Load & $5 / 13$ & 28.3 & $5 / 13$ & 15.1 & $5 / 13$ & 3.71 & $5 / 13$ & 85.7 & $5 / 13$ & 22.0 & $5 / 20$ & 21.6 & $5 / 20$ & 2.11 & $6 / 16$ & 0.467 \\
\hline
\end{tabular}

(Conc: $\mu \mathrm{g} \cdot \mathrm{1}^{-1} \quad \mathrm{Load}: \mathrm{mg} \cdot \mathrm{s}^{-1}$ )

恋瀬川では 6 月 1 日にも高いピークがあった。河川水 中の濃度は小桜川で高く, 川又川, 恋瀬川と下流ほど 低くなる傾向が見られた。MEPは，他の農薬と異なっ た流出傾向を示し，降雨後にのみ祫出された。

水田除草剤は, 移植前後加ら移植後 1 週間までに初 期除草剤，移植後 $1 \sim 2$ 週間後に中期除草剤の散布が 行われる ${ }^{61.10)}$ 。しかし, 近年, 除草剂の散布を一度で珮 ませる一発処理剤が開発され，除草剤の主流となって いる。一発処理剤も散布時期から 2 つに分類され，初 期除草剤である BUT, PRE, PYR 等を含を混合剂( ンオール粒片，ク少カリン粒剂等) は移植直後から7 〜10日以内に用いられる。一方, MFN, ESP の混合剂 (アクト粒㓮，フジグラス粒剤等）は移植後 5 日から15 日の間に施用するとなっている ら，以下のような特徵が明らかとなった。

初期除草剂の成分は 5 月中旬までの早い時期に大半 が流出している。特に, PRE, BUT は 5 月 8 日の濃度 が5月10日より常に高く, BUT はSt. 1 において 4 月 27日に低濃度ながらすでに検出されていた。一方, MFN は, 全地点で5月 8 日から検出されたが，5月20 日以降も高濃度で検出さ机流出負荷量も大きい。6月 に入ると濃度は徐久に低くなるが，St. 1，5，6では 6 月26日にも0.1〜0.2 $\mu \mathrm{g} \cdot l^{-1}$ と低漂度ながら検出さ れ，流出が長期にわたっている。ESPもMFNについ で長期間検出され，5月15日㥧まではBUTより低濃 度で推移するが, その後はBUTより高濃度となり 6 月中旬まで検出されている。しかし，いずれの除草骩 も流出ピークは同じ時期に見られた。これらの結果は, 各農薬の施用時期とよく一致している。

なお，一部の地域で 6 月 5 日前後にBUT, 10日前後 にESP の濃度が上昇している。これは 5 月末から 6 月 初旬に一部の水田で移植が行われた影響と思われる。
また，農薬の濃度は土曜日から週の前半に高くなり， 週末に向かって低くなる傾向が見られ，萧業軖家が多 いことから農薬散布がおもに土・日曜日に行われてい ることが明らかとなった。

畠山ら (4)致死濃度以下であっても複合影響でヌカ エビの死亡率が著しく増大することを埌告している。 今回の調疽で, 移植後 1 週間頃から多くの農䒩が同時 に高濃度検出されることから，水生生物への影響が奬 念される。特に，噥業人口の減少や兼業農家の增加に より, 省力化のもと，各種薬剤の同時施用や一斉散布 が多くなることが予想され，薬成の適正施用や散布後 の水管理等に十分配慮することが望まれる。

\section{2 農薬の降雨時流出特性}

降雨時流出調查を行った 5 月15～17日は，除草剈散 布の最盛期にあたり，河川水中の除草剂濃度が最も高 い時期である。殺虫剤は，まだそれほど高い濃度には なっていない。また，この5月15～16日の降雨は，全 調查期間中の一降雨としては降水量, 降雨強度とも大 きな規模のものであり，河川水質に与元る影響が最も 大きかったものと推定される。

溶存態の MFN, BUT, BPMC, MEP の濃度と流出 負荷量の経時変化を降水量と流量の変化とともに Fig. 6 に示す。降雨は 5 月15日16時から17時の時間降 雨 $4 \mathrm{~mm}$ で始まり, 19時に㹥最大時間降雨 $7 \mathrm{~mm}$ を記 録した。その後一日弱まるが，16日0時から７時まで 時間降雨 $1 \sim 3 \mathrm{~mm}$ で降り続き, 最終は 9 時の $1 \mathrm{~mm}$ であった。

調査開始時には，河川はすでに増水して抢り，初期 流出㹥捉觉ることができなかった。しかし，流量の最 大ピークは16日 5 時 (Rf-3) に現れており, 一降雨に よる流出量の部洒は十分可能と思われる。これまでの 小桜川での降雨時流出の钼測結果から降雨流出の開始 


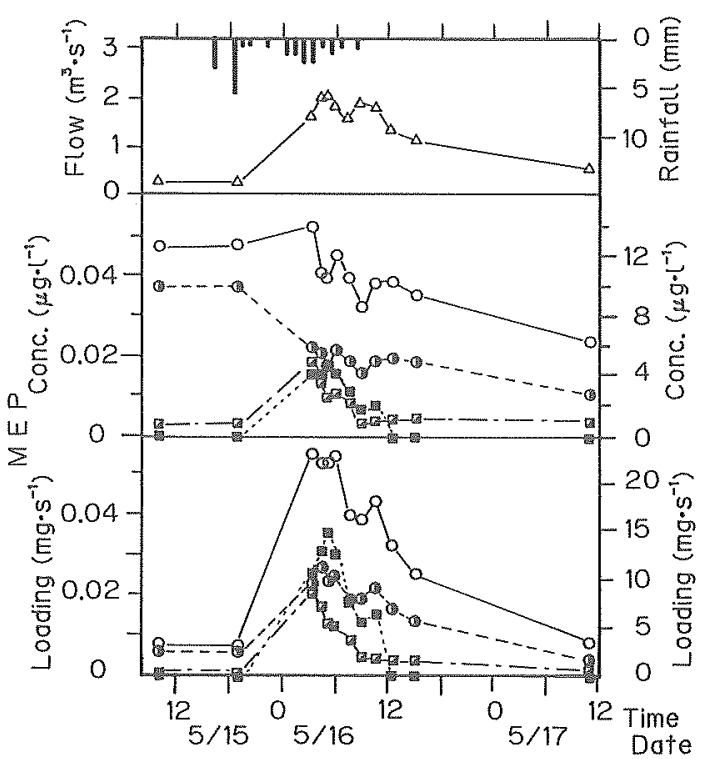

Fig. 6 Changes in concentration and loading of dissolved pesticides at the rainfall event

$\triangle:$ Flow rate $\mathrm{O}: \mathrm{MFN}$; $\mathrm{BUT}$;

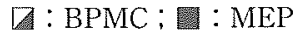

時刻 (Rf-0) を強い降雨が記録された15日19時と推定 し，17日11時 (Rf-10) 壳での40時間家一降雨流出とし た。なお，初期值としては15日10時に行った定期調沓 のテータを用いた（Table 4 参照。

流量の変動には，2つのピークが見られた。最大流 量はRf-3 の2.01 $\mathrm{m}^{3} \cdot \mathrm{s}^{-1}$ で, Rf- 6 の第二のピーク（流

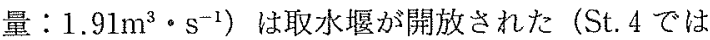
$8: 30$ 䪸) ための増水である。

除草剤と殺虫剤では異なる流出パターンを示し，さ らにそれぞれが2つの夕イプに分けられる。

除草剂の第 1 のタイプはBUTでその特徵が明瞭に 見られ，河川流量の增加とともに濃度は低下し，途中

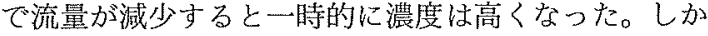
し，常に初期濃度より低く推移し，最終的に初期溲度 の約30\%まで低下した。ESP，PREも同様の变化を示 し，最終濃度は初期濃度のそれぞれ約 $65 \%$, $25 \%$ とっ た。PYR 当 Rf-1，Rf-4，Rf-7に，それぞれ0.30, $0.32,0.27 \mu \mathrm{g} \cdot l^{-1}$ (初期值 $: 0.57 \mu \mathrm{g} \cdot l^{-1}$ ) 検出され て扔り，同様の変化をしているものと考えられる。

第 2 のタイブは MFN で，Rf-1 で初期濃度の12.6 から14.1 $\mu \mathrm{g} \cdot l^{-1}$ まで上昇した。その後はBUTと同椂 の変化を示し,最終濃度は初期濃度の約 $50 \%$ となった。 流出負荷量は雨タイプとも河川流量が増加すると多 くなる傾向を示すが，流量ピークと負荷量ピークは一 致していない。RF-5，Rf-6 を谷として2つの大きな

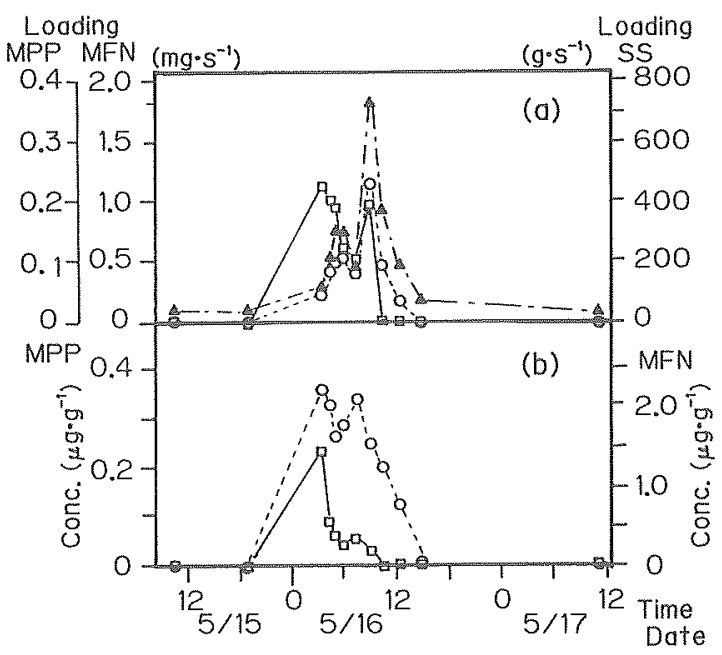

Fig. 7(a)Changes of loadings of insoluble pesticides at the rainfall event

(b)Changes of concentration of pesticides in suspended solids
盛: SS;
O:MFN:
$\square: M P P$

ピークに分けられ，第10ピークには，さらに小さな 2 つのピークが見られる。第 1 の夕イプと第 2 のタイ プで最大負荷量は異なる時刻に見られたが，ともに最 大流量より早く現れ，その後のピークは流量ピークの 直後に見られた。そして流量のピーク時にはいずれも 流出負荷量は低くなる傾向が見られる。

殺虫剤では，俵度と流出負荷量の変化は同じ傾向を 示した。殺虫片の第10夕イプはBPMCで，Rf-1で 漂度，鿓荷量とも最大となり，その後徐々に低下した。 Rf-6以降は传喓一定となるが，常に初期值より高く 推移した。MPPも BPMC と同じ変化を示した。

MEP は流量の最大ピーク時（Rf-3）に濃度，流出 負荷黨とも最大を示した。その後，徐々に減少するが Rf- 7 で濃度，流出負荷量ともわすかに高くなり，Rf -8以降は検出されなくなった。

次に，䍘濁態での流出が見られたMFNとMPPに ついて，SS と懸濁態での流出負荷量および単位 SS 重

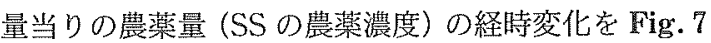
に示す。䜿濁態 $\mathrm{ESP} の$ 検出はRf-6 $\left(0.25 \mu \mathrm{g} \cdot l^{-1}\right)$ の 1 回だけであった。MFN \&SSと同じ流出パターン を示したが，MPPはRf-1で流出負荷量は最大とな り，SS と䜿濁態 MFN がともに最大となるRf-6でも 增加するが，Rf-1の約85\%にとどまった。

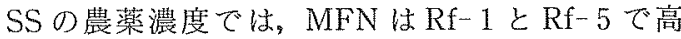
く，MPPはRf-1 で高いが，Rf-5ではわずかに濃度 が高くなる程度であった。SSの流出負荷量が多いRf $-3 ， 4 ， 6$ では，MFN，MPP とも低くなる傾向が見 
Table 4 Comparison of cumulative loadings of mefenacet with observation frequency

\begin{tabular}{|c|c|c|c|c|c|c|c|c|}
\hline Date & e & $\angle$ Pime & $\begin{array}{l}\text { Loading } \\
\left(m g \cdot s^{-1}\right)\end{array}$ & $\begin{array}{l}\text { Pattern1 } \\
(\mathrm{g})\end{array}$ & $\begin{array}{l}\text { Rainfall } \\
(\mathrm{g})\end{array}$ & $\begin{array}{l}\text { Pattern2 } \\
(\mathrm{g})\end{array}$ & $\begin{array}{l}\text { Pattern3 } \\
\text { (g) }\end{array}$ & $\begin{array}{l}\text { Patternd } \\
(\mathrm{g})\end{array}$ \\
\hline $5 / 01$ & Wed. & $11: 40$ & 0 & 0 & & & & \\
\hline 08 & Yed. & $11: 15$ & 0.76 & 294 & & 295 & 295 & 459 \\
\hline 10 & Fri. & $10: 45$ & 1.44 & 310 & & 312 & 312 & \\
\hline 13 & Mon. & $10: 45$ & 7.92 & 1703 & & 1711 & 1711 & \\
\hline 15 & Wed. & $10: 10$ & 3.21 & 325 & & 416 & 554 & 1941 \\
\hline & $R f-0$ & $19: 00$ & 3.21 & 99 & & & & \\
\hline 16 & $R f-1$ & $03: 20$ & 23.2 & 404 & 399 & & & \\
\hline & $R f-2$ & $04: 35$ & 21.8 & 67 & 103 & & & \\
\hline & $\operatorname{Rf}-3$ & $05: 00$ & 21.7 & 57 & 33 & & & \\
\hline & Rf -4 & $06: 00$ & 22.6 & 104 & 82 & & & \\
\hline & Rf -5 & $07: 30$ & 16.8 & 93 & 109 & & & \\
\hline & $\mathrm{Rf}-6$ & $09: 00$ & 16.4 & 95 & 94 & & & \\
\hline & Rf-7 & $10: 30$ & 18.4 & 119 & 98 & 1627 & & \\
\hline & Rf-8 & $12: 30$ & 13.6 & 111 & 117 & & & \\
\hline & $R \hat{f}-9$ & $15: 00$ & 10.5 & 424 & 109 & & & \\
\hline $5 / 17$ & Fri. & $11: 00$ & 3.23 & 532 & 493 & 558 & 698 & \\
\hline 20 & Mon & $10: 25$ & 4.02 & 865 & & 868 & 868 & \\
\hline 22 & Wed. & $10: 40$ & 6.69 & 866 & & 867 & 867 & 4045 \\
\hline 23 & Thu. & $10: 20$ & 2.29 & 692 & & 692 & 692 & \\
\hline 29 & Yed. & $10: 30$ & 1.51 & 586 & & 586 & 586 & 911 \\
\hline $6 / 01$ & Sat. & $10: 25$ & 1.85 & 481 & & 480 & 480 & \\
\hline 04 & Tue. & $10: 40$ & 2.27 & 392 & & 392 & 392 & \\
\hline 05 & Wed. & $10: 20$ & 1.01 & 348 & & 349 & 349 & 610 \\
\hline 12 & Wed. & $10: 30$ & 0.29 & 137 & & 137 & 137 & 175 \\
\hline 16 & Sun. & $10: 30$ & 0.50 & 152 & & 152 & 152 & \\
\hline 19 & hed. & $10: 25$ & 0.11 & 48 & & 48 & 48 & 68 \\
\hline 26 & Wed. & $10: 15$ & 0 & 0 & & 0 & 0 & \\
\hline \multicolumn{3}{|c|}{ Total Discharge } & & 9304 & 1637 & 9490 & 8141 & 8209 \\
\hline
\end{tabular}

5 京长。

以上の結果から，除草郕之殺虫剂の流出特性に明ら かな違いが認められた。また，殺虫㓮でも MEP の流出 が MPPなどと異なることが示された。MEPは，他の 瑟藻がすべて倹出された降雨前には検出されないこ と，河川流量の最大ピークと湮度，流出負荷量の最大 值が一致することから，MEP 标もに水田以外から の流出によるものと考えられる。

溶存態の流出では殺虫剤は除草剤と異なり，後平の 流出負荷量ピークが見られない。すなわ方，殺虫剂は 初期流出で多く流出し，水田の残留量が除草剤より速 く隇少したことを示すものである。今回の調查結果か ら，除草剂之殺出剂の水田土簑への吸着残留性と流出 特性の違いが明らかとなったが，秌虫剂の散布湃が除 草剂のそれに比べ少ないため，このような見かけ上の

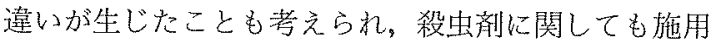
最盛期の降雨時流出調查など，より詳紏な調香が必要 と思われる。

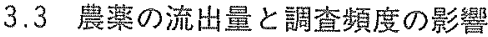

降雨時流出調盖を行ったSt. 4 の調查結果より，4つ の調龺パターン（調㭗頻度）を想定し総流出負荷量を 求めた。その棓算結果を MFNを例に Table 4 に示す。
Table 5 Relative total loadings calculated with pat. tern 2 and other patterns

\begin{tabular}{|l|c|c|c|c|c|}
\hline & Rainfall & Pattern 1 & Pattern 2 & Pattern 3 & Pattern 4 \\
\hline F I OW & 0.065 & 0.99 & 1.00 & 0.95 & 0.85 \\
BUT & 0.237 & 0.97 & 1.00 & 0.81 & 0.84 \\
PRE & 0.214 & 0.97 & 1.00 & 0.87 & 1.11 \\
PYR & 0.274 & 0.55 & 1.00 & 0.41 & 1.44 \\
ESP & 0.137 & 0.97 & 1.00 & 0.85 & 0.80 \\
MFN & 0.172 & 0.98 & 1.00 & 0.86 & 0.86 \\
BPMC & 0.088 & 1.04 & 1.00 & 0.97 & 1.30 \\
MPP & 0.097 & 1.05 & 1.00 & 0.93 & 1.88 \\
MEP & 0.052 & 0.98 & 1.00 & 0.97 & 0.90 \\
\hline
\end{tabular}

一降雨による総流出負荷量 $(\mathrm{Rf}-0$ ～10) についても一. 緒に示した。

パターン 1 は隆雨時流出調相の 9 回のデータも含め た全データから，棌水間隔を時間単位てとり，算出し た総流出蕒荷量で方る。

パターン 2 は定時・定点観測のデータから，採水間 䧣を日単位として求めた総流出負荷量である。降雨時 調査については16日10時30分（Rf-7）のデー夕を用い $t_{0}$

パターン3はパターン2から5月16日の降雨データ 㐋除いた総流出鱼荷量である。

パターン4は每遠 1 回水壦日の定期調查から算出し た総流出負荷量である。

パターン 1 とパターン 2 では, PYR 以外はほ国同じ 
流出負荷量が得られ，降雨後の増水持に調査を行うこ とにより降雨時流出をカバーできることがわかる。

次に,パターン2とその他のパターンの総流出負荷 量との比を Table 5 に示す。

各農薬の一降雨総流出負荷量は調査期間中の総流出 負荷量に対し，除草剤で20 25\%，殺虫骭で 5 〜 $10 \%$ であった。このためパターン 3 にる五総流出負荷量は， パターン 2 に対し殺虫㣚で約 $95 \%$ ，除草骭で81 87\% であった。まだ散布のピーク時期でない殺虫郕では データの削除による影響はそれほど大きくないが，除 草㲢は散布のピーク時にあたり，この1回の降雨調査 を省いただけで約15\%過小に見積もられたことにな る。

パターン 4 では $80 \%$ から約 2 倍まで大きく変動して いる。水田用農薬は, 散布される時期が限定されてお り，検出期間も比較的短期間であることから，週 1 回 の定期調查だけでは流出量を定量的に評価することは 難しいと思われる。特に，PYR は検出頻度が極端に少 なく，検出の継続時間も数時間加ら長く見積もっても 2〜3日と見られる。もし，週 1 回の定期調査で検出 されたとすると，その流出負荷量に 7 日間の流出期間 がかけられ過大に算定することになる。逆に調査間隔 が長い場合には検出されないことも考えられ，正確な 総流出負荷量が得られないことになる。したがって， PYRの上うな検出期間の短い成分の流出特性を知る ためには，散布直後からできるだけ短い調查間隔で流 出を把握する必要がある。

海老瀬 ${ }^{11}$ は栄養塩等の負荷量の算定においても，高 流量時に高い流出負荷量を呈する成分について，每週 1 回の調查では降雨時の流出真荷量を正確に見積もる ことができず不十分であるとしている。農薬も降雨時 の流量増加に伴い高負荷量を与兄，しかも，流出期間 も短期間に限定されることから，降雨の影響を十分考 慮して調査を行うことが重要である。

\section{4 農蔡の流出率}

農薬の流出率を求めるためには，前節で検討した流
出量とともに, 調查流域での宸薬施用量の把握が重要 である。しかし，施用実態を正確に把握することは大 変困難である。ここでは, 調査流域への嶩薬の販売量 が最も多いと考兵られる農協からの出荷量を基に流出 率の算定を試みた。Table 6 亿調查地点流域に扔ける 水田1ヘクタール（ha）当たりの施用量を示した。本 調查流域（St. 6) で最も施用量の多かった農薬は, MFN て780kg，次いで ESP470kg，MPP390kg の䐓 で，最小はPREの60kgであった。しかし，同一啫協 内であっても地区每に出荷される農薬の種頑や量が異 なっており，他農協間ではさらに大きな違いのあるこ とが明らかとなった。したがって，この調査流域では， 農薬毎に指定され九標準施用量 ${ }^{10}$ や県内全域への出荷 量汤らでは正確な流出率を求めることはできない。

Table 7 亿調查地点每の各農薬の流出率と水溶解 度 ${ }^{12) 133}$ を示した。また，丸147炕よて示されたライジ メーターでの水溶解度と流出率の回㷌式上り求めた流 出率も併せて示した。流出率の算定には，パターン 3 の流出負荷量を用い，St. 4 についてはパターン 2 によ る流出率も併せて示した。

Fig. 8 に水溶解度と流出率の関係を図示した。農藻 の流出率は水溶解度と相関が高い(10),14,15 ことが報告 されており，同様の結果が得られた。PYRの流出負荷 量は前節で述べたように正確さに欠けるが，流出し難 い農薬であることは確かである。

MEP の流出率は非常に小さい。これ注，出荷量調㚗 でMEP の混合剤であるトラサイド A，パーマチオン 等の呇，ぶどう，梨等に用いられる農薬が出荷されて 扔り，招もに全耕地面積の10２0\%を占める樹園地か らの流出であると考えられる。

St. 1 は除草剤の流出率が他の地点と比べ常に小さ い傾向が見られる。これはSt. 1 の河川の比流量が小さ いこともあり，灌溉用水の取水による影響と考えられ る。

今回得られた流出率を全体的に見ると，一部の農薂 を除き小桜川のSt. 2, 3 で高い流出率が得られ，流下

Table 6 Specific cumulative discharge and amount of applied pesticides

\begin{tabular}{|c|c|c|c|c|c|c|c|c|c|}
\hline & Dischage & BUT & PRE & PYR & ESP & MFN & BPHC & MPP & MEP \\
\hline St.1 & 87.58 & 153 & 28.1 & 106 & 414 & 366 & 153 & 282 & 222 \\
St.2 & 148.4 & 157 & 29.6 & 111 & 467 & 383 & 157 & 294 & 210 \\
St.3 & 140.9 & 157 & 29.6 & 111 & 468 & 383 & 157 & 293 & 209 \\
St.4 & 131.4 & 168 & 30.0 & 114 & 421 & 394 & 168 & 305 & 255 \\
St.5 & 138.1 & 213 & 31.9 & 125 & 262 & 437 & 213 & 356 & 403 \\
St.6 & 136.7 & 148 & 38.6 & 154 & 301 & 503 & 148 & 248 & 243 \\
\hline
\end{tabular}

(Discharge: $\times 10^{3} \mathrm{~m}^{3} \cdot \mathrm{kg}^{-2}$

Pesticides: $g \cdot h a^{-1}$ ) 
Table 7 Runoff rate of applied pesticides from observation areas with runoff pattern 3

\begin{tabular}{|c|c|c|c|c|c|c|c|c|}
\hline & BUT & PRE & PYR & ESP & MFN & BPMC & MPP & MEP \\
\hline Solubility $\left(\mu \mathrm{g} \cdot \mathrm{ml}^{-1}\right)$ & 20 & 50 & 0.9 & 4.9 & 4.0 & 660 & 55 & 14 \\
\hline Runoff rate $(\%)$ & & & & & & & & \\
\hline St. 1 & 4.85 & 9.78 & 0.00 & 3.02 & 7.99 & 23.2 & 1.28 & 0.021 \\
\hline St. 2 & 7.99 & 11.6 & 0.40 & 4.58 & 11.7 & 24.8 & 1.63 & 0.069 \\
\hline St. 3 & 7.65 & 12.1 & 0.33 & 5.18 & 12.2 & 23.9 & 1.49 & 0.049 \\
\hline St. 4 & 6.81 & 14.1 & 0.13 & 4.60 & 12.5 & 13.1 & 0.85 & 0.043 \\
\hline St. 5 & 6.02 & 16.5 & 0.58 & 4.52 & 10.9 & 9.42 & 0.80 & 0.100 \\
\hline St. 6 & 5.95 & 14.0 & 0.69 & 3.68 & 10.0 & 9.42 & 0.59 & 0.082 \\
\hline $\mathrm{St} .4$ a & 8.39 & 16.2 & 0.32 & 5.40 & 14.5 & 13.5 & 0.87 & 0.046 \\
\hline Runoff rate ${ }^{b}(\%)$ & 6.29 & & & & 9.10 & 17.1 & 2.17 & 3.14 \\
\hline Runoff rate $c(\%)$ & 9.04 & 12.2 & 3.3 & 5.71 & 5.35 & 28.4 & 12.6 & 8.05 \\
\hline
\end{tabular}

a: Calcuration with pattern 2 ; b: Runoff from lysimeter test 14)

c: Calcuration with regression equation ${ }^{14)}(\log [Y]=0.531+0.327 \log [X] \quad X:$ solubility Y:runoff rate )

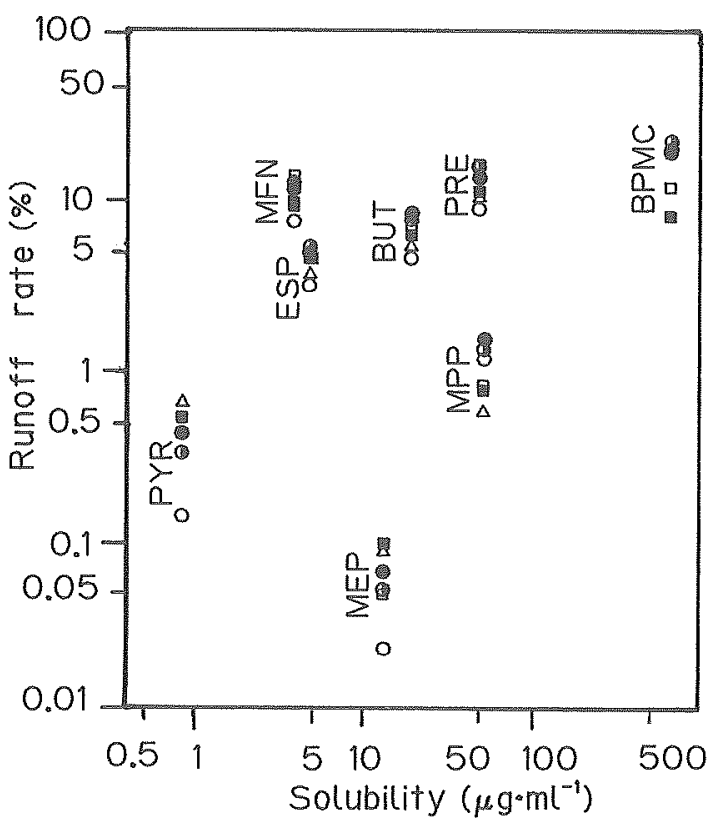

Fig. 8 Relationship between solubility and runoff rate

$$
\begin{aligned}
& \bigcirc \text { :St. } 1 ; \text { : St. } 2 ; \text { : St. } 3 \text {; } \\
& \square \text { :St. } 4 \text {; : St. } 5 ; \triangle \text { : St. } 6
\end{aligned}
$$

に伴い低くなっている。飯塚是けは水田面積が広く流下 距離が長くなるほど分解, 揮散, 土壤吸着等が促進さ れ流出率が低下するとしている。降雨時流出の際，SS の流出負荷量が最大の時に懸濁態の MFN, MPP の流 出が多くなったこと，BPMCの流出負荷量が St. 3 と
4 の間でかなり少なくなることなどから，分解と土懐 吸着を生じているものと考えられる。しかし，殺虫剤 の流出率の低下は，殺虫剤が収檴前まで数回にわたつ て施用されることから, 農協からの出荷量のうち一部 は使われずに農家にストックされていることも一つの 要因と考学られる。また，灌溉水の繰り返し使用が農 薬の流出量評価に与える影響, 水田土壕八の残留, 河 川底質への吸着, 水中での分解など, 環境中での農薬 の動態に関してさらに詳紐な検討が必要である。

\section{4. 結論}

水稲移植期に每週水矅日の定期調査と降雨時抒よび 降雨後の追加調查を行い，農薬の流出特性と流出負荷 量を明らかにした。また，各調査地点毎の農薬出荷量 調査を基に祳薬施用量と流出率について検討し，以下 の結果が得られた。

1）水稲移植期に施用される農薬は，湛水状態で用 いられるため散布直後よりおもに溶存態で河川水中に 検出された。

2）除草剤の流出は移植後 $1 \sim 2$ 週間後にピークが 見られ，MFN，ESPは，BUT，PRE，PYRより長期 間検出された。

$3 ）$ 殺虫率は除草骫より約 1 週間から10日遅れて流 出ピークが見られた。

4) 降雨時流出調査の結果，除草郕は総流出負荷量 の20 25\%が一降雨で流出し，農薬の環境中への流出 を言価するには，施用最盛期における降雨時の調査が 
重要である。

5）除草戍と殺虫剂で降雨時流出に扔いて異なった 流出パターンを示し，殺虫剂は降雨初期に多く流出す ることが認められた。

6) 蜄藻の総流出負荷量を求めるためには週 1 回の 調盖頻度では不十分であり，降雨による流出を考慮し た詳細な調㚗を行う必要がある。

7) 移植後 1 週間頃から多種類の農桬が同時に高濃 度検出され水生生物への影響が懸念される。

8）調查地点每の農薬出荷量調楂の結果，同一町村 内であって当地区毎に出荷量に大きな違いが見られ to

9) 降雨影響を考慮し調查を行った結果，今までの 河川への流出率より大きい流出率が得られ，この值は 試験田等による流出率に近い結果となっている。 謝 辞

本研究を行うにあたり，ICIジャパン(獭，石原産業 (株)，日本チバガイギ一維，日本バイエルアグロケム姝 の各社には農薬標準品のご提供を，茨城県の農拹には 農薬の出荷量調査にご拹力をいただいた。また，国立 環境研究所環境化学部伊藤裕康，芹沢茂子雨氏には GC-MSによる農薬の同定を扔願いした。ここに記し て深く感謝の意を表します。

(原稿受付 1992年5月31日) (原稿受理 1992年8月3日)

\section{引用文垶}

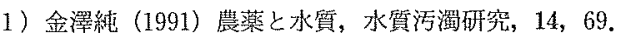

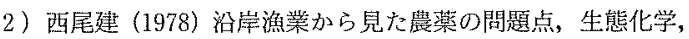
$1,131-148$.

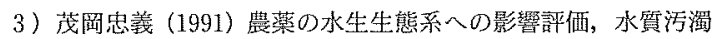
研究, 14, 88-91.

4 ）畕山成久, 白石宽明, 浜田篤信 (1991) 霞ヶ湤水系河川のヌ カエビ (Paratya compressa improvisa) 生物武験による農薬惯 性の季節変勤, 水貿污渴研究, $14,460-468$.

5) 御鲪初子, 宮原和夫 (1983) 佐賀県に扔ける水田地带のクリ一 ク水の䢉䕓による污染，生態化学，6，23-33。

6) 丸諭 (1985) 千葉県内河川の㖘薬モニタリング, 生態化学, $8,3-10$.

7) Shiraishi, H., Pula, F., Otsuki, A. and Iwakuma, T. (1988) Behaviour of pesticides in Lake Kasumigaura, Japan, Sci. Total Environ., 72, 29-42.

8 ）海老潪潜一，井上隆信（1991）支流の合流伴う河川流下過 程に扔りる水質変化坒の定量評洒, 水質污濁研究, 14, 243-252.

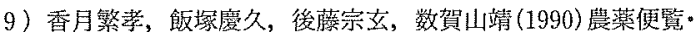
第 7 版, 農山漁村文化協会.

10）飯塚宏栄（1989）水田除草剂の水系に扔ける動態，䄀業環境 技街仾究所報告, 6, 1-18.

11）海老瀨潜一（1988）流域からの热機イオン流出負荷量原単位 と流出特住，国立公宫研究所報告，116，111-131.

12）富澤長次郎, 上路雅子, 满岡政二(1989)最新宸菜データブッ ク、ソフトサイエンス社.

13）日本植物防疫協会（1985）㸃薬ハンドブック.

14）丸諭（1990）水田ライシメーダーからの農薬流出と水溶解度 の関係, 日本㹃蔡学会誌，15, 385-394.

15）渡辺貞夫, 渡辺重信, 伊藤和御（1984）モデル水田における 除草骫 (CNP, Molinate, Simetryne) の水系への流出と土壤 中での消長, 日本農薬学会誌, 9, 33-38. 